\title{
UPACARA ADAT BUANG JUNG pada Masyarakat Suku Sekak di Bangka
}

\author{
Fidyan Fajriana \\ Program Studi Magister Manajemen Sumber Daya Pantai
}

\begin{abstract}
Rules, norms, views, traditions or customs embody social system supporters, who later formed the customary tradition. One of the customs is a traditional ceremony of Buang Jung conducted by fisherman's community in Bangka Island. The ceremony was carried out because of the belief in forces beyond human abilities such as God of the Sea. This ceremony is called Buang Jung (meaning boat offering), since a jung (mini boat) is thrown into the sea as an offering of Sekak Tribe to the god of the sea.
\end{abstract}

Key words: Ritual, boat offering, Sekak Tribe, god of the sea, Bangka Island.

\section{Pendahuluan}

Masyarakat Indonesia terdiri dari berbagai macam suku bangsa, dan masing-masing suku bangsa mempunyai kebudayaan dengan adat istiadatnya masing-masing. Setiap suku bangsa memiliki budaya yang khas, yang membedakannya dari suku bangsa lainnya yang tersebar di wilayah Indonesia, salah satu di antaranya adalah upacara adat (customary ritual) (Achroni, 2008). Adat kebiasaan pada dasarnya teruji secara alamiah dan niscaya bernilai baik, karena kebiasaan tersebut merupakan tindakan sosial yang berulang-ulang dan mengalami penguatan (reinforcement) (Sartini, 2004).

Suku Sekak yang mendiami pesisir Pulau Bangka merupakan salah satu suku bangsa di Indonesia yang dikenal dengan tradisi laut yang begitu kuat. Mereka hidup dan berbudaya selama berabad-abad di laut dengan memegang teguh nilai-nilai kehidupan yang diturunkan oleh para leluhurnya dan membangun kebudayaan yang unik. Matapencaharian mereka adalah mencari ikan, sebagai nelayan. Secara teologis, nelayan masih memiliki kepercayaan yang kuat bahwa laut memiliki kekuatan magis sehingga perlu perlakuan-perlakuan khusus dalam melakukan aktivitas penangkapan ikan agar keselamatan dan hasil tangkapan semakin terjamin (Satria, 2002).

Keyakinan akan alam gaib masih dilestarikan oleh para leluhur orang-orang tua masyarakat Suku Sekak, antara agama dan kepercayaan melebur menjadi satu; dengan kata lain, kekuatan ilahi dan kekuatan gaib merupakan mata rantai yang tidak terpisah. Hubungan tersebut menunjukkan bahwa tidak semua hal dapat diberikan jawaban secara konkret, ada 
sesuatu di luar kekuasaan manusia. Semua ini memberikan tafsiran kepada manusia untuk mengadakan upacara agar hal-hal yang tidak diinginkan akan menjadi netral dan pendekatanpendekatan untuk mendapatkan kebahagiaan dan kesenangan. Tanggapan manusia terhadap alam lingkungannya melahirkan berbagai upacara.

Hal ini ditunjukkan dengan adanya kegiatan upacara adat yang dilakukan berkaitan dengan peristiwa alam dan kepercayaan yang rutin dilakukan oleh masyarakat Suku Sekak. Upacara adat ini dinamakan upacara Buang jung. Dikatakan demikian karena dalam upacara ini sebuah jung (kapal) berukuran mini, berikut dengan perlengkapan lainnya berupa barangbarang sesajen dan balai penonang, dilayarkan dan dibuang ke laut lepas sebagai persembahan Suku Sekak kepada Dewa Laut. Upacara ini dilakukan oleh Suku Sekak berdasarkan kepercayaan dan adat kebiasaan yang turun-temurun dari nenek moyang mereka (Hasan dkk, 1993).

\section{Suku Sekak dan Upacara Buang Jung}

\section{1. Suku Sekak}

Suku Sekak merupakan suku orang laut yang mendiami wilayah pantai di bagian utara Pulau Bangka yang membentuk kelompok etnis dan mempunyai pola hidup unik. Sekarang ini Suku Sekak tidak lagi merupakan suku terasing karena mereka sudah beradaptasi dengan budaya dari luar. Mata pencaharian mereka adalah sebagai nelayan. Hampir seluruh hidup mereka dihabiskan untuk mengarungi lautan dan memperoleh hasil tangkapan ikan.

Suku Sekak merupakan rumpun bangsa melayu dengan bahasa dan dialek yang hampir mirip bahasa Melayu namun ada perbedaan yang cukup mencolok antara Suku Sekak atau orang Sekak dibandingkan dengan orang-orang yang mendiami Pulau Bangka lainnya. Contoh kalimat bahasa Sekak dan artinya dalam bahasa Indonesia, seperti berikut.

\begin{tabular}{|l|l|}
\hline Bahasa Sekak & Bahasa Indonesia \\
\hline Akuq neq pegiq ke Plimeng & Aku akan pergi ke Palembang \\
\hline Ikan nyeng iko jual puqbik & Ikan yang kamu jual tidak bagus \\
\hline
\end{tabular}

(Hasan dkk, 1993).

Berbagai kebudayaan menganut kepercayaan bahwa dunia gaib dihuni oleh berbagai makhluk dan kekuatan yang tak dapat dikuasai oleh manusia dengan cara-cara biasa, dan karena itu dunia gaib pada dasarnya ditakuti oleh manusia (Koentjaraningrat, 2005). Sebagian besar Suku Sekak masih menganut kepercayaan aninisme dan dinamisme, namun akhir-akhir ini ada yang menganut agama Islam dan Kristen. Sistem religi mereka biasanya terdiri dari 
unsur-unsur keyakinan, upacara, dan ilmu gaib yang berkaitan erat dengan persepsi dan konsepsi mereka mengenai laut dan alam sekitarnya. Dewa Laut bagi masyarakat Suku Sekak seiring waktu telah memengaruhi budaya organisasi sosial masyarakat, terutama dalam memilih sang pemimpin. Masyarakat Sekak memilih pemimpin dari orang-orang dalam kelompoknya yang memiliki kelebihan berupa kekuatan gaib, serta dapat berkomunikasi dengan Dewa Laut, dengan harapan sang pemimpin terpilih dapat sekaligus menjadi pemimpin upacara penghormatan ritual Dewa Laut (Pramono, 2005).

\section{2. Upacara Buang jung}

Pada prakteknya, manusia hidup bermasyarakat diatur oleh suatu aturan, norma, pandangan, tradisi, atau kebiasaan-kebiasaan tertentu yang mengikatnya, sekaligus merupakan cita-cita yang diharapkan untuk mencapai maksud dan tujuan tertentu yang sangat didambakannya. Aturan, norma, pandangan, tradisi, atau kebiasaan-kebiasaan itulah yang mewujudkan sistem tata nilai untuk dilaksanakan masyarakat pendukungnya, yang kemudian membentuk adat-istiadat (Darmoko, 2002). Adat istiadat merupakan suatu kompleks normanorma yang oleh individu-individu yang menganutnya dianggap ada di atas manusia yang hidup bersama dalam kenyataan suatu masyarakat (Koentjaraningrat, 1969). Upacara adat (customary ritual) adalah kegiatan sosial yang melibatkan warga masyarakat dalam usaha bersama untuk mencapai tujuan keselamatan bersama. Upacara-upacara yang berhubungan dengan adat suatu masyarakat, merupakan sistem aktivitas atau rangkaian tindakan yang ditata oleh adat atau hukum yang berlaku dalam masyarakat yang berhubungan dengan berbagai macam peristiwa tetap yang biasanya terjadi dalam masyarakat yang bersangkutan (Soekanto, 1990). Upacara adat sebagai pranata sosial penuh dengan simbol-simbol yang berperan sebagai alat media untuk berkomunikasi antara sesama manusia, dan juga menjadi penghubung antara dunia nyata dengan dunia gaib (Achroni, 2008).

Upacara Buang jung merupakan salah satu upacara adat yang secara turun-temurun dilakukan oleh masyarakat Suku Sekak di pulau Bangka. Upacara ini diadakan karena adanya keyakinan dan kepercayaan masyarakat Suku Sekak terhadap Dewa Laut dan adanya kekuatan-kekuatan lain yang berasal dari dunia adikodrati. Upacara ini merupakan refleksi dari keinginan untuk hidup harmonis dengan alam, sehingga para nelayan percaya bahwa jika mereka memperlakukan laut dengan tidak baik maka laut akan marah kepada mereka sehingga kehidupan sosial-budaya terganggu.

Upacara adat Buang jung diadakan setahun sekali, yaitu waktu menginjak bulan purnama pada bulan ganjil, kira-kira jatuh pada bulan Juli atau September atau menurut 
perhitungan penanggalan cina pada bulan kelima bertepatan pada musim angin tenggara yang sangat kencang. Penyelenggaraan upacara diadakan di perkampungan Suku Sekak, di sekitar laut di mana mereka hidup, seperti di desa Kumbang, Kecamatan Lepar Pongok, Kabupaten Bangka dan di Tan jung Labu, Kabupaten Belitung. Pelaksanaan upacara adat Buang jung diadakan di pinggir pantai dan kemudian menuju laut bebas. Pihak-pihak yang terlibat dalam upacara Buang jung adalah seluruh masyarakat Suku Sekak.

Upacara Buang jung dilaksanakan dengan tujuan untuk menyampaikan persembahan kepada Dewa Laut, agar kiranya Dewa Laut memberikan isi laut (berupa ikan, lumut laut dan hasil-hasil laut lannya) kepada mereka, dengan memohon kepada Dewa Laut agar mereka terhindar dari segala macam balak (malapetaka) dan kemelaratan; upacara ini juga merupakan hiburan, karena pada saat itu mereka, Suku Sekak, dapat berkumpul untuk bersuka-ria, setelah bekerja keras (Hasan dkk, 1993).

\section{2. 1. Perlengkapan Upacara Buang jung}

Dalam menjalankan upacara Buang jung, masyarakat Suku Sekak memerlukan beberapa perlengkapan yang harus disediakan. Perlengkapan yang diperlukan dalam upacara Buang jung terdiri atas jung (perahu mini), balai penonang, tiang jitun, seperangkat sesajen dan Tempa.

jung (perahu mini) adalah sebuah perahu kecil yang panjangnya 4 (empat) meter dengan layar terbuat dari kain berwarna putih, dilengkapi sebuah keranjang (raga) Tempat meletakkan seperangkat sesajen yang akan dipersembahkan kepada Dewa Laut. Pada bagian atas, depan dan belakang jung terdapat beberapa hiasan lukisan berbentuk manusia membawa senjata berupa senapan pendek dan panjang yang melambangkan awak kapal. jung yang dibuat dihiasi beranekaragam hiasan dari daun kelapa muda atau janur dan kertas krep. jung dicat menggunakan cat minyak warna putih, merah, hijau, dan cat buatan sendiri dengan bahan campuran arang, kunyit dan kapur.

Balai penonang adalah replika rumah-rumahan berbentuk limas terbuat dari kayu yang dihiasi dengan janur, kertas krep dan dicat. Balai penonang yang dibuat untuk upacara Buang jung berjumlah 4 (empat) buah, 3 (tiga) buah balai dibuat dengan ukuran $1 \mathrm{X} 1 \mathrm{~m}$ dan 1 (satu) balai dibuat dengan ukuran yang lebih besar dan kuat yang akan digunakan dalam upacara balai.

Tiang Jitun adalah tiang yang akan dipasang di pantai Tempat upacara Buang jung akan dilaksanakan, terbuat dari kayu gelam yang dipertemukan segitiganya dan dipaku serta 
diikat dengan seutas tali. Tinggi tiang jitun yang dipasang adalah 6 (enam) depa atau 9 (sembilan) meter.

Tempa adalah saluran air yang terbuat dari kayu-kayu kecil (anak laras) yang disusun dan dilapisi dengan tikar dan kain. Tempa ini berfungsi sebagai Tempat memandikan para pelaksana buang jung sehabis mereka melaksanakan tugas.

\section{2. 2. Tahapan Upacara Buang jung}

Keseluruhan proses ritual memakan waktu hingga 2 (dua) hari 2 (dua) malam. Upacara Buang jung dilaksanakan dalam tiga tahap yaitu tahap sebelum upacara, tahap pelaksanaan upacara dan tahap sesudah upacara, sebagai berikut..

\section{(1) Tahap Sebelum Upacara}

Sebelum upacara Buang jung dilaksanakan terdapat beberapa kegiatan yang dilakukan, yaitu penentuan waktu pelaksanaan upacara, penyampaian berita kepada para perangkat upacara, masyarakat dan pemerintah daerah seTempat sekaligus pencarian dana untuk keperluan upacara, penentuan hutan sebagai lokasi pengambilan kayu sebagai bahan untuk membuat jung dan perlengkapan lainnya.

Sebelum upacara buang jung dilaksanakan dukun melakukan ritual untuk menentukan pelaksanaan waktu upacara. Dukun dalam menentukan hari dan tanggal pelaksanaan upacara didasarkan kepada kebiasaan yang selama ini dilakukan. Penentuan waktu pelaksanaan upacara dilakukan oleh dukun dengan melakukan semedi dan membaca mantra-mantra berupa biang (doa) yang disertai sesajen. Penetapan hari dan tanggal pelaksanaan upacara dapat diputuskan bila dukun mendapat isyarat, keyakinan akan dibolehkannya dilakukan upacara - agar tujuan diadakannya upacara terkabul dan tidak ada sesuatu yang akan menjadi halangan; sebaliknya apabila dalam semedi dukun mendapat isyarat atau petunjuk pelaksanaan upacara tidak boleh dilaksanakan maka pelaksanaan upacara harus ditunda agar tidak menentang mara bahaya dan menimbulkan korban. Kegiatan selanjutnya sang dukun memberitahukan kepada para perangkatnya dan masyarakat Suku Sekak. Khusus pemberitahuan kepada pemerintah daerah, disampaikan langsung oleh lurah Suku Sekak sekaligus untuk meminta ijin dan meminta bantuan dana.

Tahap selanjutnya sebelum pelaksanaan upacara Buang jung adalah membuat perlengkapan yang dibutuhkan untuk upacara seperti jung, balai dan Tempa. Untuk membuat perlengkapan, dukun memimpin upacara untuk menentukan lokasi hutan di mana kayu akan diambil untuk membuat perlengkapan. Setelah lokasi dan syarat yang diminta oleh roh halus sudah diketahui, maka berita ini disampaikan kepada masyarakat Suku Sekak untuk bersiap 
menuju lokasi dan mengambil kayu. Pengambilan kayu dilakukan oleh para pemuda yang masih tangguh karena dibutuhkan tenaga dan fisik yang kuat untuk mengambil kayu dan wanita yang masih muda untuk membantu dan memberi hiburan dengan bernyanyi dan menari saat para pria sedang menebang kayu. Tarian dan lagu yang dibawakan oleh wanita Suku Sekak juga merupakan persembahan kepada roh-roh halus penghuni hutan agar diperkenankan mengambil kayu. Bahan-bahan yang dibutuhkan dalam membuat perlengkapan upacara Buang jung dikumpulkan di lokasi pembuatan jung, yaitu kayu, daun kelapa (janur), cat, paku, kertas, dan kain layar berwarna putih. Daun kelapa muda yang digunakan diambil dari pohon kelapa milik masing-masing anggota Suku Sekak yang ada di lokasi upacara.

Proses pembuatan perlengkapan jung dipimpin langsung oleh dukun dengan melibatkan semua penduduk Suku Sekak. Pembuatan perlengkapan upacara harus selesai dalam waktu satu hari. Setelah pembuatan perlengkapan upacara selesai dikerjakan, tiang jitun dipasang di tepi pantai, sementara balai dan jung diTempatkan di posisinya masingmasing.

Kegiatan dilanjutkan dengan upacara balai dan naik tiang jitun. Upacara ini dilakukan pada malam hari di bawah sinar bulan purnama. Bila pada malam yang telah ditentukan keadaan cuaca kurang baik seperti adanya badai atau angin ribut maka acara diundur pada pagi atau siang hari berikutnya. Sebagai tanda akan dimulainya acara, gong dan gendang dibunyikan oleh penduduk kampung agar seluruh masyarakat Suku Sekak berkumpul menuju Tempat upacara dilakukan.

Sebelum pelaksanaan upacara balai dan naik tiang jitun dimulai, dukun memeriksa segala perlengkapan yang dibutuhkan dalam upacara seperti pemasangan tiang jitun dan membentangkan sebuah tikar di antara tiang jitun dan jung, di depan tikar diletakkan baskom berisi air, talam yang di dalamnya terdapat mayang pinang yang terbungkus kain putih, semangkuk beras, kunyit, dupa yang sudah dihidupkan dan beberapa buah kemenyang. Apabila semua persiapan sudah lengkap, sang dukun duduk diatas tikar dan didampingi 2 (dua) orang pembantunya yang bertugas mengatur perlengkapan upacara dan sebagai penawar apabila ada yang kerasukan saat upacara berlangsung. Di belakang dukun duduk pemukul gong dan penabuh gendang serta 7 (tujuh) orang penangkap iblis. Penangkap iblis bertugas untuk menangkap peserta upacara yang kesurupan saat upacara berlangsung untuk dibawa ke perempuan yang bertugas sebagai penawar. Sang dukun memulai upacara dengan menaburkan kemenyan di atas dupa sambil membaca biang dan diiringi oleh gendang dan gong. Setelah selesai membaca biang sang dukun mengambil balai dan meletakkan balai di 
antara kedua pundaknya, sedangkan tangan kanan memegang salah satu sisi balai dan tangan kiri memegang sisi yang lain dan mulai mengayunkan balai mengikuti irama gendang dan gong yang dibunyikan sambil mengucapkan:

Balai penonang klanggeng,

Rumah pengayun klanggeng,

Balai penonang klanggeng,

Kalu la milu klanggeng, jangen la mabu

Setelah dukun selesai membawa balai, secara bergantian balai dibawa oleh para pembantu dukun. Apabila saat membawa balai ada pemain yang kesurupan akan digantikan dengan pemain lain dan penangkap iblis akan menangkap orang yang kesurupan untuk dibawa ke perempuan penawar untuk disadarkan dengan mengibas-kibaskan mayang pinang ke badan orang yang kesurupan. Acara balai penonang selesai dilakukan apabila sudah tidak ada lagi pemain yang bergantian untuk membawa balai. Kemudian acara dilanjutkan dengan upacara menaiki tiang jitun, seperti pada acara balai sang dukun membaca biang sehingga dukun dalam keadaan tidak sadar. Dalam kondisi tidak sadar sang dukun bangkit dan mengangkat kedua tangannya sambil mengucapkan biang. Sebagai awal dimulainnya upacara naik tiang jitun, perempuan pengurus upacara menyingkirkan talam yang berisi mayang pianang dan dupa untuk memberi kesempatan kepada dukun memanjat tiang jitun. Saat dukun memanjat tiang jitun, gendang dan gong terus dibunyikan diikuti dengan penangkap iblis mengelilingi tiang jitun sambil menari dan perempuan pembantu upacara mengiringinya sambil menembangkan lagu. Pada saat dukun menaiki tiang jitun iringan gendang dan gong tidak boleh berhenti sampai dukun turun ke tanah.

Menurut mereka jitun adalah kayu besar dan sang dukun menaiki tiang jitun karena ditarik oleh puteri jawa, sehingga orang yang ada di bawah jitun harus terus menyanyi. Hal ini dilakukan dengan harapan agar naik tiang jitun dengan seizin puteri jawa, tidak ada aral melintang dan dukun dapat turun dengan selamat. Saat dukun turun dari tiang jitun dengan posisi kepala menghadap ke bawah. Setelah turun dari tiang jitun, penangkap iblis membimbing dukun menuju perempuan penawar untuk menyadarkan dukun dengan mengibas-kibaskan mayang pinang.

Upacara naik tiang jitun selanjutnya dilanjutkan oleh para pembantu dukun. Para pembantu dukun sebelum secara bergantian menaiki tiang jitun terlebih dahulu ditaburi beras kunyit dan dikibaskan mayang pinang. Acara naik jitun berakhir bila sudah tidak ada lagi yang menaiki tiang jitun. 
Setelah upacara balai dan upacara naik tiang jitun selesai, dilanjutkan dengan joged yang dilakukan oleh para pemuda Suku Sekak. Joged diiringi dengan lagu-lagu seperti lagu Dalung, Ya Ali dan Gajah Manunggang. Terdapat nyayian khusus yang diberikan dukun untuk dinyanyikan masyarakat Suku Sekak untuk menunggu datangnya fajar dan menunggui segala perlengkapan upacara Buang jung sebelum pelaksanaan upacara dilaksanakan. Lagu yang dinyanyikan seperti lagu Daek, Adoi-Adoi dan Cingadeg dengan cara menyanyi dengan mengelilingi perlengkapan upacara dan lagu dinyanyikan secara bergantian dan bersahutsahutan. Bila fajar telah datang maka pelaksanaan upacara selanjutnya dilakukan kembali oleh para pelaksana upacara buang jung.

\section{(2) Tahap Pelaksanaan Upacara}

Pelaksanaan upacara buang jung dimulai dengan mempersiapkan dan memeriksa segala peralatan yang diperlukan yang dilakukan sebelum matahari terbit. Dukun memerintahkan kepada petugas arak-arakan dengan cara berjalan kaki untuk keliling kampung yang dimulai dari u jung dusun menuju arah tepi laut, pantai di mana upacara akan dilaksanakan. Barisan arak-arakan diiringi dengan bunyi-bunyian dari gong dan gendang. Tujuan arak-arakan untuk mengajak dan memberitahu warga untuk menyaksikan acara buang jung. Setelah rombongan arak-arakan tiba di pantai, dukun kembali memeriksa para pembantunya. Apabila semua sudah dianggap lengkap oleh sang dukun, maka di bawah pimpinan dukun dan para pembantunya diangkatlah jung beserta perlengkapan lainnya ke perahu layar yang telah tersedia.

Dalam perjalanan menuju tanjungan dan laut lepas gong dan gendang dibunyikan, orang-orang yang ada dalam perahu bernyanyi dan berjoget, ada di antara mereka yang dilemparkan ke laut kemudian dinaikkan kembali, sembur-semburan dengan air laut hingga sampai ke lokasi pembuangan jung. Setelah sampai di lokasi, kegiatan upacara dimulai dengan terjunnya seorang penyelam mengelilingi dan menyeberangi dasar perahu untuk mengetahui apakah Tempat pembuangan jung sudah aman dari gangguan iblis laut. Kegiatan selanjutnya adalah dialog antara sang dukun yang berada di atas perahu selaku penyampai persembahan Buang Jung dan perlengkapan lainnya dengan penyelam yang bertindak mewakili Dewa Laut. Penyelam tersebut biasanya sudah dalam keadaan kemasukan Dewa Laut. Dalam dialog terjadi tawar menawar, sang dukun menyampaikan niatnya memberikan persembahan kepada Dewa Laut yang diwakili para penyelam Suku Sekak dan diminta agar menerima persembahan yang diberi, dan Dewa Laut bertanya apa yang dikehendaki oleh dukun, maka dukun mengatakan supaya Dewa Laut memberikan kepada mereka isi laut 
sebagai imbalannya. Apabila telah terjadi kesepakatan, maka jung diturunkan perlahan-lahan ke laut beserta isinya berikut dengan balai besar. Bersamaan dengan ini diikuti pula pembuangan 1 (satu) balai di darat dan 2 (dua) di tanjungan yang semuanya dilakukan setelah mendapat isyarat dari dukun. Saat pembuangan jung dan balai, si penyelam yang mewakili Dewa Laut melintas di bawah jung yang diturunkan sebagai isyarat atau tanda persetujuan terhadap persembahan yang diberikan dan memberikan pengamanan jung dari gangguan iblis laut. Setelah semua acara pembuangan jung selesai (jung dan balai sudah tenggelam), sang dukun memanggil penyelam yang mewakili Dewa Laut untuk naik ke perahu. Setibanya di atas perahu oleh pengurus upacara si penyelam dikembalikan kesadarannya dengan membaca biang atau lagu:

Pulang kekire pulang ade guru

Lakile ade guru kekire la mulang

Yang memiliki arti mengajak ia kembali, supaya semangatnya pulih kembali jangan tinggal di dalam laut. Setelah semua selesai para pengikut upacara meminta kepada Dewa Laut untuk mohon diri dan kembali ke darat. Dalam perjalanan ke darat mereka tetap bergembira dan bernyanyi hingga sampai di tepi pantai.

\section{(3) Tahap Sesudah Upacara}

Setelah pelaksanaan upacara Buang Jung selesai, rombongan pemBuang Jung kembali ke pantai dan dibawa ke Tempa (Tempat pemandian semacam saluran air). Di sana mereka dimandikan, agar iblis dan bau anyir dari laut mengalir dan lepas dari tubuh mereka sehingga mereka betul-betul dalam keadaan suci dan hilang dari pengaruh sial dan iblis laut.

\section{2. 3. Pantangan}

Terdapat pantangan-pantangan yang harus dihindari oleh masyarakat Suku Sekak baik sebelum, saat berlangsungnya upacara dan sesudah upacara Buang Jung dilaksanakan. Pantangan-pantangan itu meliputi, sebagai berikut.

(1) Sebelum dan selama upacara Buang Jung berlangsung tidak boleh ada perkelahian terutama bagi mereka yang terlibat langsung dalam upacara. Siapa yang berkelahi akan dikenakan sanksi masyarakat yaitu dikucilkan dari masyarakat Suku Sekak dan diwajibkan membayar ongkos pembuatan peralatan Buang jung.

(2) Warna cat yang digunakan untuk mengecat jung mini tidak boleh sama dengan warna cat perahu biasa yang dimiliki oleh masyarakat Suku Sekak. Apabila pelanggaran terhadap pantangan dilakukan akan mengundang kemarahan Dewa Laut karena dianggap 
jung beserta segala pelengkapan lainnya dan sesajen yang diberikan tidak istimewa atau tidak diberikan sebagai kehormatan bagi Dewa Laut.

(3) Selama tiga hari sesudah memBuang Jung, para peserta upacara yang terlibat langsung dilarang mengambil isi laut seperti ikan, lumut laut dan sebagainya. Apabila dilakukan berarti yang bersangkutan akan mengundang sial.

(4) Peserta upacara yang berstatus penonton, apabila ditangkap oleh pengambil iblis tidak boleh lari atau melawan, sebaiknya ia mengikuti saja, untuk dibawa ke pengurus upacara untuk dikebas dengan mayang pinang. Jika yang bersangkutan lari atau melawan maka ia dianggap sial karenanya harus diusir dari kegiatan upacara.

(5) Peserta yang mengikuti upacara buang jung di laut harus ikut mandi di Tempa walaupun sedikit saja, jika air tidak mengenai badan atau pakaiannya, maka ia menurut kepercayaan akan dihinggapi kesialan.

\section{2. 4. Lambang dan Makna dalam Unsur Upacara}

Lambang dan makna yang terkandung dalam unsur-unsur upacara yang terdapat dalam pelaksanaan upacara Buang jung adalah sebagai berikut.

(1) Jung (perahu mini) melambangkan kapal yang akan dipakai Dewa Laut sebagai persembahan Suku Sekak.

(2) Cat yang digunakan untuk mengecat jung, balai dan sebagainya, yang berbeda dari warana cat yang biasa dipakai oleh perahu penduduk, yang dimiliki Suku Sekak, melambangkan bahwa kesukaan Dewa Laut diberi sesuatu yang istimewa, lain dari yang lain.

(3) Seperangkat sesajen melambangkan atau alat penukar yang diberikan oleh Suku Sekak kepada Dewa Laut yang nantinya Dewa Laut akan menukarnya dengan memberikan ikan hasil tangkapan dan berbagai hasil laut lain kepada masyarakat Suku Sekak.

(4) Balai berbentuk limas, melambangkan sebuah rumah yang akan dipersembahkan kepada Dewa Laut oleh Suku Sekak.

(5) Pemakaian warna putih untuk ikat kepala dukun, kain layar dan pembungkus mayang pinang melambangkan kesucian.

(6) Warna merah (bahan campuran kapur dengan kunyit) dan hitam arang merupakan kebiasaan yang diwariskan oleh nenek moyang mereka.

(7) Sang dukun mengangkat kedua tangannya melambangkan suatu permohonan atau yang mereka minta dengan biang atau doa sang dukun.

(8) Semua pekerjaan dikerjakan bersama-sama melambangkan bahwa maksud pelaksanaan upacara demi kepentingan bersama. 
(9) Keterlibatan semua anak laki-laki dan perempuan, tua dan muda dari seluruh penduduk, melambangkan bahwa acara ini merupakan hajat seluruh masyarakat Suku Sekak.

\section{Simpulan}

Suku Sekak merupakan satu suku di Indonesia yang tinggal di wilayah pesisir Bangka dan masih melestarikan tradisi secara turun temurun, yaitu upacara adat Buang Jung, upacara adat yang berkaitan dengan peristiwa alam dan kepercayaan. Upacara ini dilaksanakan setiap satu tahun sekali oleh masyarakat Suku Sekak, karena masih adanya kepercayaan terhadap kekuatan gaib di luar kemampuan manusia. Kekuatan di luar kemampuan manusia ini diartikan sebagai Tuhan Yang Maha Esa atau kekuatan super natural seperti Dewa Laut.

Sebagai pranata sosial, upacara adat Buang Jung penuh dengan simbol-simbol yang berperan sebagai alat media untuk berkomunikasi antara sesama manusia dan juga menjadi penghubung antara dunia nyata dengan dunia gaib. Melalui simbol-simbol, nilai-nilai etis, pesan-pesan ajaran agama dan norma yang berlaku dalam masyarakat dapat disampaikan kepada semua warga masyarakat. Upacara adat sebagai warisan budaya dan mengandung nilai-nilai yang mempunyai corak kepribadian bangsa Indonesia sebagai salah satu pendukung dalam pembentukan jati diri bangsa perlu untuk tetap dilestarikan. Salah satu cara yang dapat dilakukan adalah dengan menginventarisasikan upacara adat yang ada, sehingga upacara-upacara adat tetap lestari.

\section{Daftar Pustaka}

Achroni, Dawud. 2008. Upacara Adat Nusantara. Surakarta: Suara Media Sejahtera.

Darmoko. 2002. "Ruwatan: Upacara Pembebasan Malapetaka - Tinjauan Sosiokultural Masyarakat Jawa,” Jurnal Makara, Sosial Humaniora, Vol 6, No 1 (Juni 2002): 31.

Hasan, Hambali dkk. 1993. Upacara Tradisional dalam Kaitannya dengan Peristiwa Alam dan Kepercayaan Daerah Sumatera Selatan. Departemen Pendidikan dan Kebudayaan, Kantor Wilayah Propinsi Sumatera Selatan, Bagian Proyek Penelitian, Pengkajian dan Pembinaan Nilai-Nilai Budaya Sumatera Selatan.

Keesing, Roger M. 1989. Antropologi Budaya: Suatu Perspektif Kontemporer. Terjemahan. Jakarta: Erlangga.

Koentjaraningrat. 1969. Pengantar Antropologi. Jakarta: PD Aksara. 2005. Pengantar Antropologi II. Jakarta: Rineka Cipta.

Pramono, Djoko. 2005. Budaya Bahari. Jakarta: PT Gramedia Pustaka Utama. 
Sartini. 2004. "Menggali Kearifan Lokal Nusantara Sebuah Kajian Filsafati," Jurnal Filsafat, Jilid 37, Nomor 2 (Agustus 2004): 112.

Satria, Arif. 2002. Pengantar Sosiologi Masyarakat Pesisir. Jakarta: PT Pustaka Cidesindo.

Soekanto, Soerjono. 1990. Sosiologi - Suatu Pengantar. Jakarta: PT Raja Grafindo Persada. 